\title{
Key Factors Influencing Pricing Strategies For Small Business Enterprises (SMEs): Are They Important?
}

\author{
Michael Colin Cant, University of South Africa, Pretoria, South Africa \\ Jan Wiid, University of South Africa, Pretoria, South Africa \\ Catherine Mpolokeng Sephapo, University of South Africa, Pretoria, South Africa
}

\begin{abstract}
Price is a critical component for any business and can be crucial in the survival of the business. If the price is not set in line with the selected target market it can negatively impact on the product and the company's profitability. The main goals of any profit seeking organisation is to make a profit and in order to achieve this goal all areas related to the management of the product, costs and the setting of the price need to be managed correctly. The primary aim of this study was therefore to investigate the factors considered by small business enterprises (SME's) when developing their pricing strategies. To address this problem adequately, the research methodology was based on the primary data collected from South African SMEs. As SME's show common traits all over the world, it is accepted that any findings will be universally applicable. A questionnaire was distributed to 88 SMEs to gather relevant data regarding factors considered when determining prices. The data was quantified and analysed by examining the frequency of occurrences and the importance of the problem. The study found that SME's generally agree that price setting is influenced by competitor information and macro environmental factors such as fuel prices and inflation. There was a general agreement amongst the SME's that consumers relationships and the benefits that they, the consumers enjoy form the product as well as product performance are important aspects to consider when determining prices.
\end{abstract}

Keywords: Pricing; Influences On Pricing Strategies; Consumers; Competitors; SMEs; Gauteng

\section{INTRODUCTION}

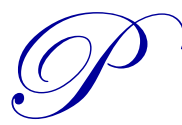

ricing can be considered to be an important aspect that impacts on the success of an organisation. The success of an organisation, depends among other things on the careful consideration of the elements of the marketing mix; namely product, price, place and promotion. Much emphasis is however placed on the promotion component by many organisations, and in the process price is neglected. Price is however very crucial in the survival of the business, and if the price is not determined correctly, this could negatively impact on the product and the company's profitability (Hub Pages, 2013). Consumers tend to use the price of a product to evaluate the perceived quality of the product offering therefore much thought needs to be placed on the pricing strategy and how goods are priced.

One of the main goals of any organisation whether an established entity or a small business enterprise; is to make a profit. This can be done through the efficient management of resources and offering a product or service at the right price. Machado (2013:3) defines price as "the value of a product or service expressed in terms of rands and cents; it is the amount of money needed to obtain such a product and the benefit or utility which goes with it". coming up with a pricing strategy is an important task within marketing because pricing is the only component of the marketing mix that generates sales profits; the other components generate costs and sales volume (Small Business Development Corporation, 2014).The type of pricing strategy that SMEs would choose to employ would depend on the objective that the pricing strategy aims to achieve. Table 1.1 explains the various types of pricing objectives that steer pricing strategies. 
Table 1. Types of pricing objectives

\begin{tabular}{|c|c|c|}
\hline \multicolumn{3}{|c|}{ Pricing objectives } \\
\hline Profit orientated & Sales orientated & Status quo orientated \\
\hline $\begin{array}{l}\text { Organisations may aim to set prices } \\
\text { that will maximise their current profits. } \\
\text { In this attempt they evaluate demand } \\
\text { and costs accompanying the alternate } \\
\text { prices and choose the price that will } \\
\text { maximise profits, income or rate of } \\
\text { return on investment. }\end{array}$ & $\begin{array}{l}\text { Sales objectives are essentially } \\
\text { expressed in terms of sales volume or } \\
\text { market share. The motivation for } \\
\text { setting sales volume objectives is to } \\
\text { create growth in sales or to sustain } \\
\text { current sales levels. }\end{array}$ & $\begin{array}{l}\text { Sales quo objectives are tactical goals } \\
\text { that encourage competition on factors } \\
\text { other than price. Organisations that base } \\
\text { their pricing strategy on this employ } \\
\text { such an orientation in order to remain } \\
\text { competitive or to avoid price battles with } \\
\text { their competitors. }\end{array}$ \\
\hline
\end{tabular}

Adapted from: Machado (2013: 70 - 71)

The discussion thus far has emphasised the importance of pricing strategies to the achievement of organisational goals. Since companies can employ various pricing strategies, it is important to investigate what factors these organisations need to consider when developing their pricing structures. The primary aim of this article is to investigate the factors considered by small business enterprises (SME's) when developing their pricing strategies. Although the focus is on SMEs in Gauteng, South Africa it is believed that the findings will be universally applicable to SMEs worldwide.

\section{LITERATURE REVIEW}

The discussion explains what encompasses a successful pricing strategy and delineates the various external as well as internal factors that small businesses may consider when determining their pricing strategies.

\section{What Encompasses A Successful Pricing Strategy?}

An effective pricing strategy ought to mirror a cohesive pricing structure that facilitates the achievement of business objectives by ensuring the value of a product/service offering compared to the value offered by competitors (Meehan, Simonetto, Montan and Goodin, 2011). A good pricing strategy should therefore direct an organisation's core behaviour as well as its peripheral communiqué to the market for all pricing-related activities (Meehan et al., 2011). A pricing strategy must be:

- Based on valid data and fact rather than on narratives and speculations therefore organisations need to evaluate key areas and make an informed decision based on the valid findings of their investigation;

- Lined up with organisational objectives as well as other functional policies and structures and

- Supple, adaptive, reactive and carefully observed.

The next discussion will provide the external and internal influences on the pricing strategy. The essence of the discussion is to highlight factors that businesses may consider when determining the right price for their product or service.

\section{External and Internal Influences on the Pricing Strategy}

When SME's develop their pricing strategies, they need to be aware of factors that can assist them in their pricing decisions. Sometimes SME's need to consider the consumer's ability and willingness to pay a premium for the product offering, if the consumer cannot afford the product they will not purchase the product even if the quality is good. Other factors that SMEs need to be aware of are illustrated in Figure 1 and will now be discussed in detail. 
Figure 1. External and internal influences on the pricing strategy

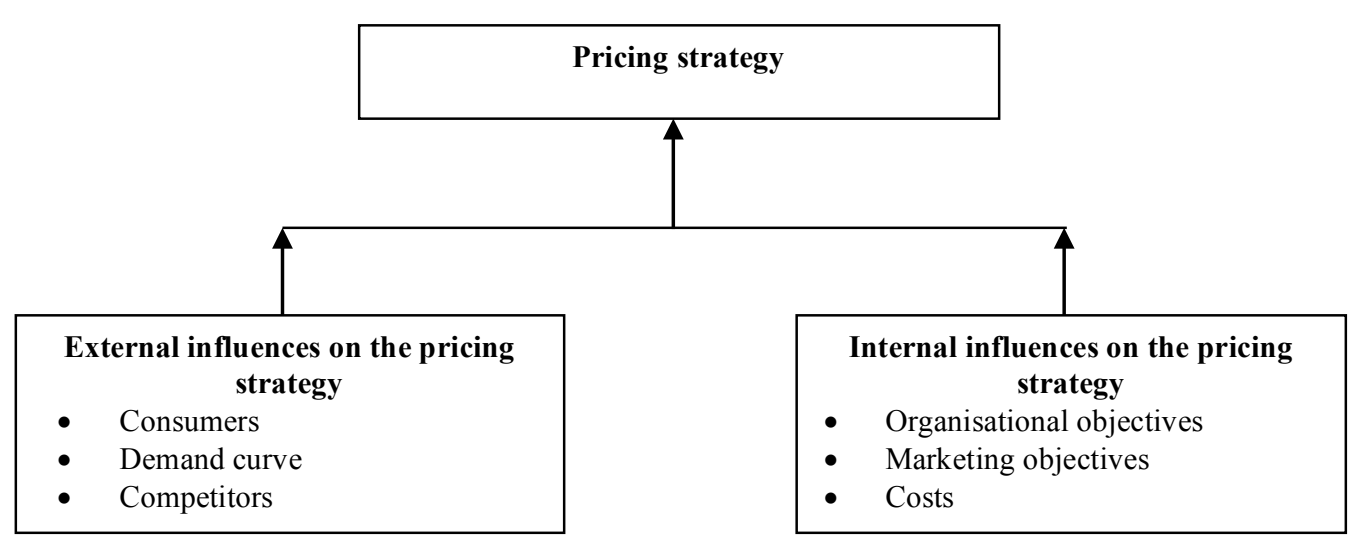

Adapted from: Brassington \& Pettitt (2013: 258 - 267)

External Influences on the Pricing Strategy

External factors that are considered to influence an organisation's pricing strategy include:

- Consumers

Consumers play a very important role in the success of a business. The main focus of organisations is to satisfy the identified needs to consumers. In the same light, consumers need to be considered when determining a suitable pricing strategy. Setting prices too low, although it may attract customers initially, it will not keep them in the long run as they will simply go elsewhere when lower prices are available (Schuler, Not Dated). SMEs need to ensure that they identify which consumers they want to attract and work on strategies to retain these consumers. In addition, the consumer's ability and willingness to pay a certain amount for a product should be considered when determining which price to set.

- Demand curve

This involves analysing the relationship between price and demand for the product or service offering that the organisation is putting in the market. According to Kotler, Armstrong, Ang, Leong, \& Hon-Ming (Not Dated), demand and price is normally inversely correlated whereby in cases where prices are high, demand for the product or service is relatively low. However, in cases where the product is seen as a luxury product, consumers may use the price as an indicator of the quality of the product (Machado, 2013: 64). The higher price can therefore increase the demand for the product and result in a positive demand curve. The relationship between price and quality is discussed later in this article. Another aspect relating to the demand curve that SMEs need to be aware of is the impact of price elasticity. The price elasticity of demand generally illustrates the response that the consumers to the change in price for a particular product or service. An inelastic demand is seen to occur when demand for a product or service barely deviations when there is a small change in the price (Kotler et al., Not Dated). And elastic demand occurs when demand for a product or service changes significantly when a small change in price is implemented (Kotler et al., Not Dated). 
Small business owners need to understand the role off price elasticity on their pricing policy. Understanding pricing elasticity offers SME owners an idea of what will happen to demand when considering a price change. Consumers are considered to be less price sensitive in the cases whereby the product consumers are interested in purchasing is unique or when it is viewed as a prestigious product; when substitutes for the product are relatively difficult to access and when the consumer's total expenditure for the product is low compared to their income (Kotler and Armstrong, 2010: 319)

It is important for SME owners to carefully consider these factors as they not only affect their pricing strategy but also provides the business with an in-depth understanding of their target market.

\section{- Competitors}

SMEs need to be aware of what their competitors are doing when setting their prices. In the case whereby a product is new on the market, high introductory prices may encourage competitors to enter the market with a similar product at a lower price (Verhage, 2014: 500). In the case of existing products, SMEs need to consider the effect of a price change on other companies. An anticipation of what the competitor might do in response to the company's price change can assist in determining what changes the company can withstand. For example, if SME's initiate a price change, would the competitors raise their prices, lower their prices or hold their prices? Brassington and Pettitt (2013: 265 - 265) highlight that the nature of the industry in which an entity operates can essentially affect the impact that competitors will have on one's pricing strategy. For example, in an oligopolistic industry; whereby there are a small number of sellers offering a particular product, SMEs may price their products or services relative to their competitors (Verhage, 2014: 500). Essentially, SME's need to establish the number of competitors within their industry and use this knowledge to anticipate their possible reaction to price increases, therefore providing the company with valuable information regarding what price to set.

\section{- Channels of distribution}

Channels of distribution are generally seen to affect the price determined by an organisation. Depending on the size of the SME, the distribution chain may flow from the manufacturer to the customer. If channel members exist, their needs and expectations must be clearly identified as each channel member will have their own desired level of profit margin and requirement to cover the costs involved in the management and distribution of the product (Brassington \& Pettitt, 2013: 264). This evidently affects the price set for the product as it adds onto the manufacturing costs (Brassington \& Pettitt, 2013: 264).

\section{- Legal and regulatory}

South Africa has advanced and controlled competition among businesses in the country through international practices (South Africa info, 2013). The Competition Act of 1998 guides institutions against restrictive pricing practices and against the abuse of dominant positions by organisations within the market (Competition Tribunal, 2014). The Act also focuses public interest and social goals such as the advancement of small business enterprises in the country, the welfares of workforces and black economic empowerment (Werksmans Attorneys, Not Dated).

Small businesses therefore need to carefully scrutinise the competition Act and ensure that they are lawful in their conduct. According to Price intelligently (2012), the following pricing practices are placed on the edge of ethics and legality and all businesses; including small businesses should bear these in mind in order to ensure that their businesses are protected:

- Price fixing is when organisations operating within the same industry collude to buy or sell goods or services at a fixed price. Companies in South Africa found guilty of such conduct can face prosecution or be fine (Moneyweb, 2007).

- Price discrimination is whereby an organisation sells the same product at different prices to different segments of the consumer markets. This strategy takes advantage of consumers who are willing to pay a higher premium for a product by hiding lower priced items from them. 
- Dumping is when a producer distributes its merchandise at a price which is below the price at which the merchandise is sold for in the marketplace of origin (Sibanda, 2014: 129). Investopedia (2016) highlight the effect of dumping to include jeopardising the fiscal feasibility of producers of the merchandise in the importing country.

\section{Internal Influences on the Pricing Strategy}

As can be seen from Figure 1, internal factors that are considered to influence an organisation's pricing decision include:

\section{- Organisational objectives}

As can be seen in Figure 1, organisational objectives are an internal influence that can be linked to the corporate strategy of the organisation. According to Brassington and Pettitt, $(2013,267)$, marketing plans and objectives have to be developed not only to meet identified customer wants and needs, but also to reveal the ambitions and desires of the company. Pricing may therefore be used to assist in signalling the direction in which the leadership of the organisation should follow or to create a clearly distinguished niche, which can then be highlighted by means of leveraging of other elements of the marketing communication mix (Brassington, \& Pettitt, 2013: 267). For example, organisations such as Flysafair, Shoprite and Pep stores in South Africa aim to provide South Africans with the lowest prices in their respective industries. On the other extreme, if the organisational objective is to project a corporate image of high quality and exclusiveness, highly prices products accompanied with high quality may achieve this objective.

\section{- Marketing objectives}

Brassington \& Pettitt, (2013: 268) highlight an important distinction between organisational objectives and marketing objectives is that organisational focus more on the operation, welfare, security and temperament of the company whereas marketing objectives are more focussed on the precise target markets and positioning within those markets. The pricing strategy chosen for a particular product should therefore complement the particular market that the organisation wishes to cater to. For example, Woolworths is an organisation well-known for its quality products. A company may have a variety of product categories each catering to varying consumer segments that may also require different approaches to pricing. The relationship between price and quality should therefore be established as organisations may offer higher premiums for products of high quality. According to Woolworths holdings (2012), the company continues to focus on the LSM $8-10$ target markets as these individuals have a higher income and are therefore will to pay higher premiums for higher quality products.

\section{- Costs}

One of the goals of organisations is to maintaining a customer base at a profit. Costs are therefore an important consideration when setting a price. Brassington \& Pettitt (2013: 270) state that defining a cost is a complicated task as both fixed and variable costs need to be considered. Organisations need to reflect on the variable costs and on the contribution towards fixed costs and base the estimated profit on the predicted levels of sales in order to ensure that in the long run, all costs are met and the accepted level of profit is made (Brassington, \& Pettitt, 2013: 270). In the short term however, it may difficult to adhere to this as the price needs to stand in a competitive and unpredictable environment and has to remain flexible within the market (Brassington, \& Pettitt, 2013: 270). For example, although fixed and variable costs may be determined, a product may need to be offered at a lower price in a different stage of the product lifecycle in order to increase sales volumes for a season.

The discussion thus far has provided the internal and external considerations when determining a pricing strategy. It can therefore be seen that the relationship between the price of a product and the quality can reflect positively or negatively upon the corporate image of the organisation. The next discussion will therefore unpack this relationship and highlight the influence thereof on businesses. 


\section{Relationship Between Price and Quality}

When setting a price for a particular product or service offering, marketers need to consider the value that consumers put on the price of a product. Organisations can better understand how to target consumers based on price and quality as depicted in Figure 2.

Figure 2. Price/Quality Matrix

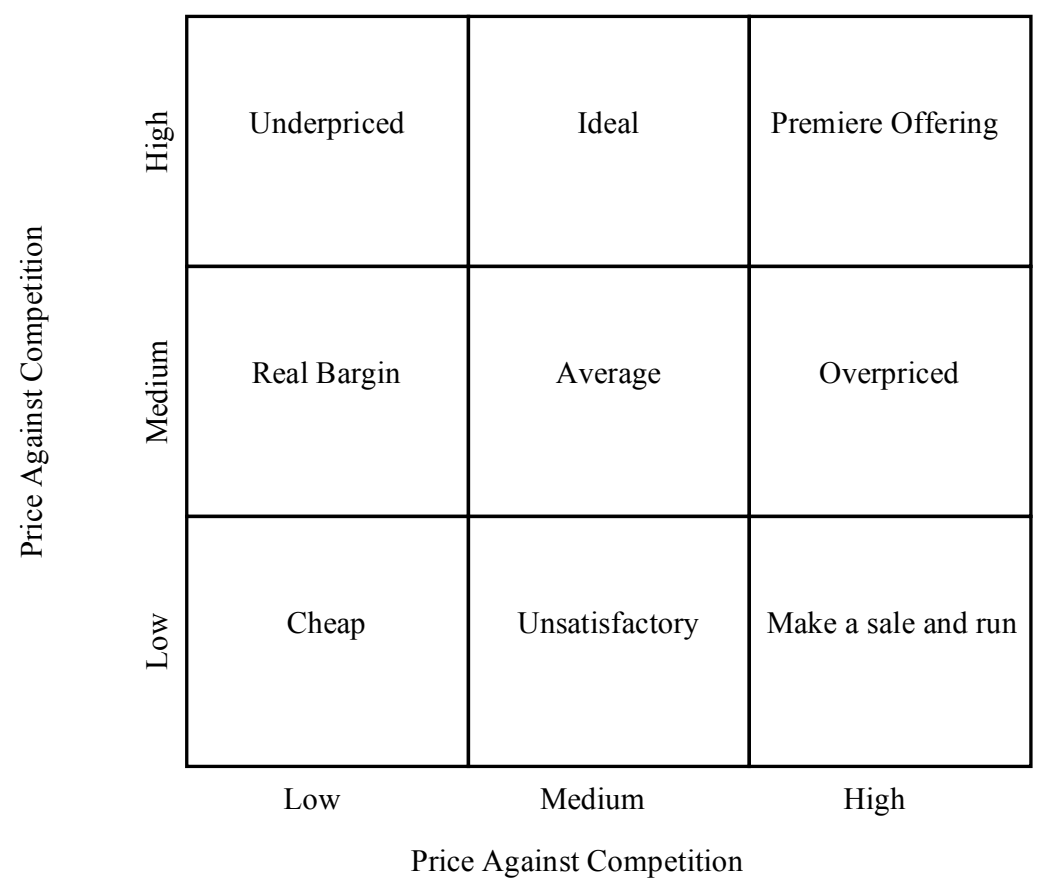

Adapted from: Marketing 91 (Not Dated); Schwarz, Hunter \& Lafleur (2013: 182)

Consumers will behave different when in different quadrants of the price/quality matrix. According to Schwarz, Hunter and Lafleur (2013: 182), businesses should refrain from operating in the high-price/low quality quantrant as consumers will simply not be willing to pay a high premium for a mediocre product. In order for an organisation to maintain a positive and fruitful relationship with consumers, a balance between price and quality needs to be established. Consumers' desire value for their money therefore quality needs to accompany the correct pricing.

The methodology employed in the study will now be discussed.

\section{AIM AND METHODOLOGY OF THE STUDY}

The aim of the study is to investigate the factors considered by small business enterprises (SME's) when developing their pricing strategies in Gauteng. A quantitative research approach was used investigate the factors considered by small business enterprises (SME's) when developing their pricing strategies in Gauteng. In order to achieve the research objective, primary data was collected from South African SMEs. To achieve a low level of error, judgement sampling method was use and a total of 88 usable responses were received and achieved an error margin of 10.26\% at a $95 \%$ confidence level and 50\% response distribution. The online Raosoft sample calculator was used to calculate the sample (Raosoft, 2004). 
The survey contained questions of a demographic nature. The sample included individuals whom $58.62 \%$ were female and $56.9 \%$ were male. The respondents were also asked to indicate whether they were owners or managers on the small business enterprise. The study found that $79 \%$ of the respondents were owners of their business and minority of the sample were managers within the small businesses. Twenty percent of the respondents indicated that they operated within the construction industry, $10 \%$ of the respondents operated within the business services industry, $10 \%$ operated within the manufacturing industry and $7.1 \%$ of the respondents operated within the retail industry. The respondents were required to indicate how long their small business had been in operation. Majority (60.8\%) of the respondents indicated that their businesses have existed for less than five years and $25.7 \%$ of the respondents' businesses have existed for six to ten years. Majority of the respondents reported that their annual turnover is less than R100000

The second set of questions, measured through Likert-type scales, investigate whether competitors prices, influence of customers and product or service offerings influence how SMEs set their prices. The Likert scale used in the study comprised of five scale points with labels ranging from strongly disagree to strongly agree. The data is measured and scrutinised by inspecting the regularity of occurrences and the importance of the problem. The research findings pertaining to SME pricing will be discussed below.

\section{RESULTS}

Descriptive statistics are used to: determine whether competitors prices influence how SMEs set their prices for products or services, establish level of communication regarding the pricing of products within the business functions of the SME, determine the influence of consumers in pricing product offerings with the organization and to establish the consideration of product or service offering when setting price setting.

The influence of competitors prices on setting prices for products or services

Respondents were asked indicate the extent to which they agree or disagree that the statements describes how aware they are of the competitors prices and if they use this knowledge to determine their prices. The agreement level is on a 1 to 5 scale from "Strongly Disagree" to "Strongly Agree". The responses for "Strongly disagree" and "disagree" was combined into a new category called "strongly disagree \& disagree" (Bottom 2). In the same way the responses for "Agree" and "Strongly agree" was combined into a new category called "Strongly agree \& Agree" (Top 2), see figure 2 . The data was sorted in descending order of the top 2 categories. It is clear from the descriptive statistics that the frequencies for all the statements are not significantly skewed from a normal distribution and can therefore be regarded as normally distributed. The frequency analysis of the questions on awareness and use of competitor's price information can be seen in Figure 3. 
Figure 3. Frequency analysis of the awareness of the competitor's prices and the use of the knowledge to set product prices

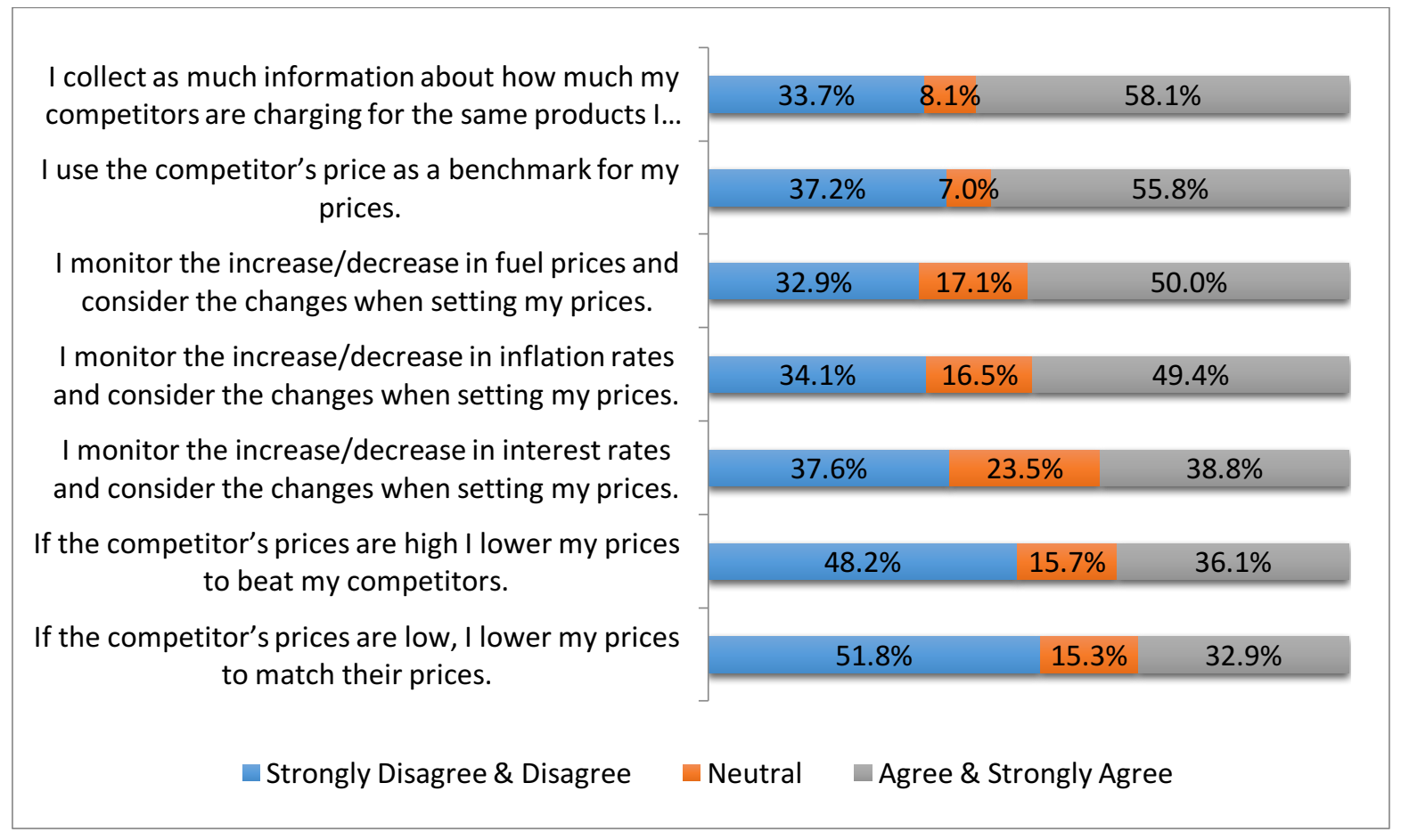

Figure 4. Experience index of the awareness of the competitor's prices and the use of the knowledge to set product prices

I collect as much information about how much my competitors are charging for the same products I sell.

I use the competitor's price as a benchmark for my prices.

I monitor the increase/decrease in fuel prices and consider the changes when setting my prices.

I monitor the increase/decrease in inflation rates and consider the changes when setting my prices.

I monitor the increase/decrease in interest rates and consider the changes when setting my prices.

If the competitor's prices are high I lower my prices to beat my competitors.

If the competitor's prices are low, I lower my prices to match their prices.

\section{$24.4 \%$}

$18.6 \%$

$17.1 \%$

$15.3 \%$

$1.2 \%$ 
From Figure 4 it can be seen that more respondents agree with the following statements than respondents who disagree

- I collect as much information about how much my competitors are charging for the same products I sell

- I use the competitor's price as a benchmark for their prices

- I monitor the increase/decrease in fuel prices and consider the changes when setting my prices

- I monitor the increase/decrease in inflation rates and consider the changes when setting my prices

More respondents disagree with the following statements:

- If the competitor's prices are high I lower my prices to beat my competitors

- If the competitor's prices are lower I lower my prices to match their prices

Almost the same number of respondents agrees and disagrees with the statement:

- I monitor the increase/decrease in interest rates and consider the changes when setting my prices

The influence of consumers in pricing product offerings.

Respondents were asked indicate the extent to which they agree or disagree that the statements describes how they consider their customers when setting the price for their product offerings. The agreement level is on a 1 to 5 scale from "Strongly Disagree" to "Strongly Agree". The responses for "Strongly disagree" and "disagree" was combined into a new category called "strongly disagree \& disagree". In the same way the responses for "Agree" and "Strongly agree" was combined into a new category called "Strongly agree \& Agree". The data was sorted in descending order of the combined category "Strongly agree \& Agree". It is clear from the descriptive statistics that the frequencies for all the statements are not significantly skewed from a normal distribution and can therefore be regarded as normally distributed. The frequency analysis of the questions considering the customers when setting the price of products within the organization can be seen in Figure 5.

Figure 5. Frequency Analysis for the questions considering

the customers when setting the price of products within the organisation

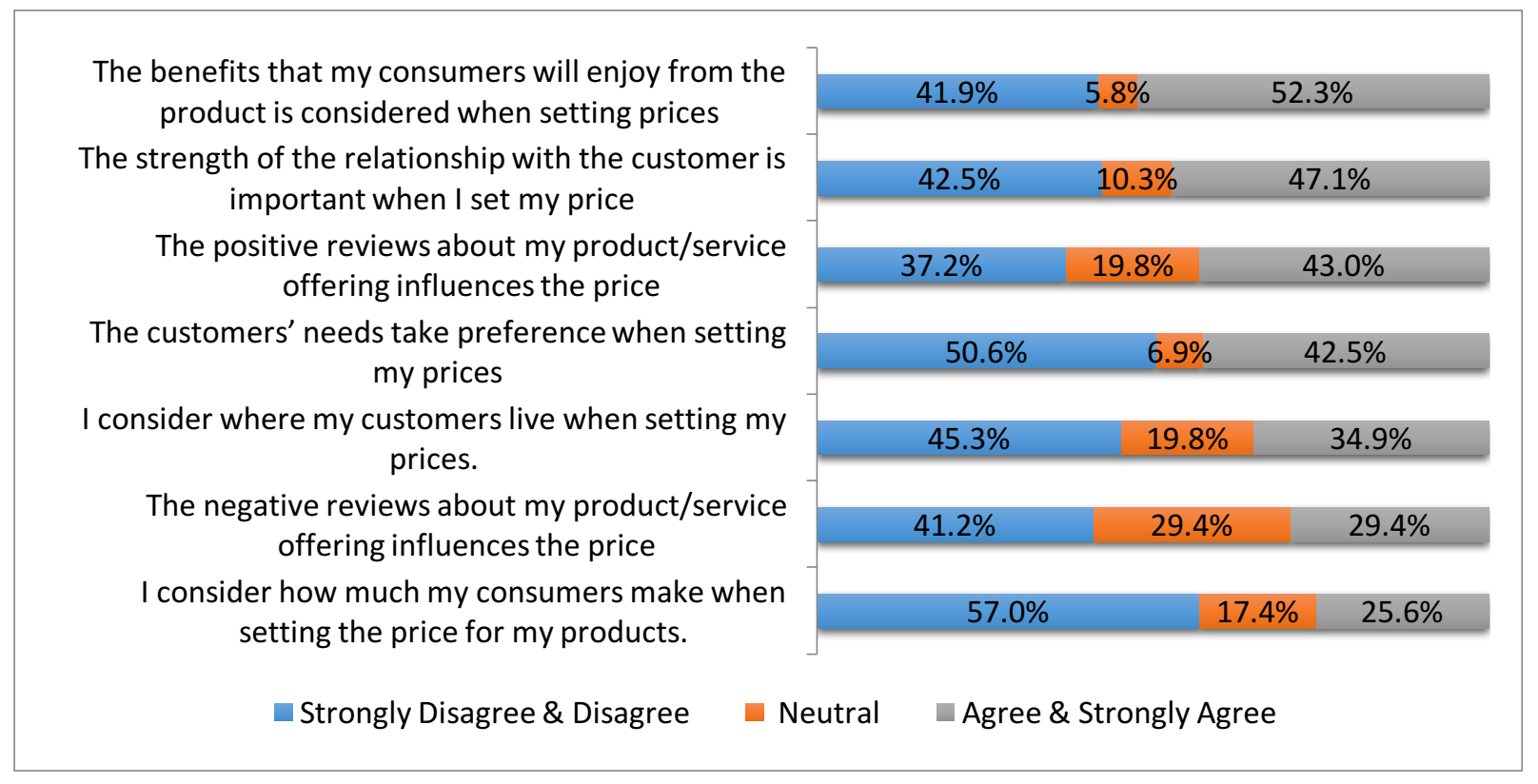


The two items with the best averages on a 5 point scale are: "The strength of the relationship with the customer is important when I set my price" $(\mathrm{n}=87)$ averaged $2.99(\mathrm{~s}=1.435)$ and "The benefits that my consumers will enjoy from the product is considered when setting prices" $(\mathrm{n}=86)$ averaged $2.98(\mathrm{~s}=1.301)$. The two items with the lowest averages on a 5 point scale are: "I consider how much my consumers make when setting the price for my products." $(\mathrm{n}=86)$ averaged $2.52(\mathrm{~s}=1.205)$ and "The negative reviews about my product/service offering influences the price" $(\mathrm{n}=85)$ averaged $2.68(\mathrm{~s}=1.227)$.

The Experience Index shows that there were more respondents selecting the top 2 ratings (strongly agree and agree) than respondents selecting the bottom 2 ratings (strongly disagree and disagree) where the EI value is positive and the opposite when the value is negative.

Figure 6. Experience Index for the questions considering the customers when setting the price of products within the organisation

The benefits that my consumers will enjoy from
the product is considered when setting prices
The strength of the relationship with the customer
is important when I set my price
The positive reviews about my product/service
offering influences the price
The customers' needs take preference when
$\quad$ setting my prices
I consider where my customers live when setting
$\quad$ my prices.
The negative reviews about my product/service
offering influences the price
I consider how much my consumers make when
setting the price for my products.

From the Experience Index in Figure 6 it can be seen that more respondents agree with the following statements than those who disagree (Positive EI values):

- The benefits that my consumers will enjoy from the product is considered when setting prices

- The strength of the relationship with the customer is important when I set my price

- The positive reviews about my product/service offering influences the price

For the rest of the statements more respondents disagree than those who agree with:

- I consider how much my consumers make when setting the price for my products

- The customers' needs take preference when setting my prices

- I consider where my customers live when setting my prices

- The negative reviews about my product/service offering influences the price

The consideration of product or service offering when setting price setting.

Respondents were asked indicate the extent to which they agree or disagree that the statements describes how they consider their products/service offering when setting the price for their product. The agreement level is on a 1 to 5 scale from "Strongly Disagree" to "Strongly Agree". The responses for "Strongly disagree" and "disagree" was combined into a new category called "strongly disagree \& disagree". In the same way the responses for "Agree" and 
"Strongly agree" was combined into a new category called "Strongly agree \& Agree". The data was sorted in descending order of the combined category; "Strongly agree \& Agree. It is clear from the descriptive statistics that the frequencies for all the statements are not significantly skewed from a normal distribution and can therefore be regarded as normally distributed. From the frequency analysis of the responses can be seen in Figure 7.

Figure 7. Frequency analysis for the questions considering

your product/service offering when setting the price of products within the organisation

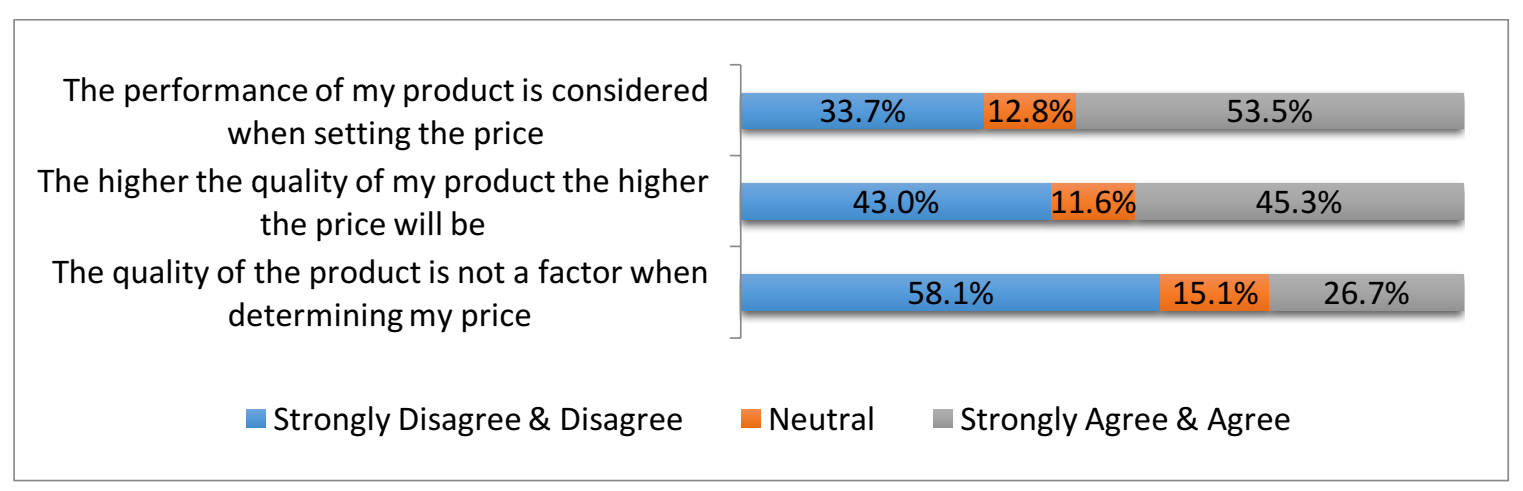

The items averages on a 5 point scale are: "The performance of my product is considered when setting the price" $(\mathrm{n}=$ 86) averaged $3.20(\mathrm{~s}=1.273)$; "The higher the quality of my product the higher the price will be" $(\mathrm{n}=86)$ averaged $2.98(\mathrm{~s}=1.178)$ and "I consider how much my consumers make when setting the price for my products" $(\mathrm{n}=86)$ averaged $2.52(\mathrm{~s}=1.205)$ and "The quality of the product is not a factor when determining my price" $(\mathrm{n}=86)$ averaged $2.58(\mathrm{~s}=1.163)$.

The Experience Index shows that there were more respondents selecting the top 2 ratings (strongly agree and agree) than respondents selecting the bottom 2 ratings (strongly disagree and disagree) where the EI value is positive and the opposite when the value is negative.

Figure 8. Experience Index for the questions considering your product/service offering when setting the price of products within the organisation

$$
\begin{gathered}
\text { The performance of my product is considered when } \\
\text { setting the price } \\
\text { The higher the quality of my product the higher the } \\
\text { price will be } \\
\text { The quality of the product is not a factor when } \\
\text { determining my price }
\end{gathered}
$$

\section{$19.8 \%$}

From the Experience index (Figure 8) it can be seen that more respondents agree than disagree with the statements that the performance of their product is considered when setting the price and that the higher the quality of the product the higher the price will be. Most of the delegates disagree that the quality of the product is not a factor when determining the price. 


\section{DISCUSSION}

Pricing is the method adopted by a firm to set its selling prices for its products and services. The price normally depends on cost elements and on the consumer's perceived value of the products and or services in comparison to competing firms, products and or services. The primary aim of this article is to investigate the factors considered by small business enterprises (SME's) when developing their pricing strategies. The study revealed that most of the respondents spend time and effort to be informed about their competitor's prices and the changes in inflation and fuel prices. Although they use the competitor's prices as a benchmark for setting their own prices, the majority of them do not adjust their prices to be lower or to match the competition's prices. The changes in interest rates and taking that into consideration when setting product prices are agreed and disagreed to by the same amount of respondents.

On the question whether customers influence the setting of product prices, the respondents indicate that most of them will consider the benefits that the customers will have from using the product, the strength of the customer relationship and positive feedback about the products or services when they set the product prices. The majority of the respondents are of the opinion that customer's needs, where they live, negative product/services reviews and how much they make do not have a big influence on setting product prices.

Most of the respondent's product prices are influenced by the performance of the products with a higher quality product being priced higher.

\section{CONCLUSION AND RECOMMENDATIONS}

The study supports the theory on price setting to a large extent. It was revealed that in general SME's agree that price setting is influenced by competitor information and macro environmental factors such as fuel prices and inflation. There is a general agreement amongst the SME's that consumers relationships and the benefits that they, the consumers enjoy form the product as well as product performance are important aspects to consider when determining prices. Given the small sample size that was used was small $(\mathrm{n}=88)$, the results only give a general indication of setting prices by South African SMEs. Therefore, the variables identified cannot be generalised as being representative of all South African SMEs further research in this area is therefore recommended.

\section{AUTHOR BIOGRAPHIES}

Michael Colin Cant - Prof. M.C. Cant, Professor in Marketing Management, Department of Marketing and Retail Management, University of South Africa. Pretoria. e-mail: cantmc@unisa.ac.za.

Jan Wiid - Prof. J.A. Wiid, Professor in Marketing Management, Department of Marketing and Retail Management, University of South Africa. Pretoria. e-mail: Jwiid@unisa.ac.za.

Catherine Mpolokeng Sephapo - Ms C.M. Sephapo, Lecturer in Marketing Management, Department of Marketing and Retail Management, University of South Africa. Pretoria. e-mail: sephacm@unisa.ac.za.

\section{REFERENCES}

Beesley, C. (2012). How to price your small business' products and services. Retrieved from: http://www.sba.gov/community/blogs/how-price-your-small-business \%E2\%80\%99-products-and-services

Boone, L. E \& Kurtz, D. L. (2011). Contemporary marketing. South-Western: Cengage learning.

Brassington, F \& Pettitt, S. (2013). Essentials of marketing, $3^{\text {rd }}$ ed. Harlow: Pearson.

Competition Tribunal. (2014). Competition Act. Retrieved from: http://www.comptrib.co.za/assets/Uploads/TheAct/Competition-Amendment-Act-1-February-2001.pdf

Investopedia. 2016. What is Dumping. Retrieved from: http:/www.investopedia.com/terms/d/dumping.asp

Hub Pages. (2013). Role and importance of pricing. Retrieved from: http://hubpages.com/business/Role-and-importance-ofpricing

Kotler, P., Armstrong, G., Ang, S. H., Leong, C. T \& Hon-ming, O. Y. (Not Dated). Chapter 10: Pricing products: Understanding and capturing customer value. Retrieved from: www.ln.edu.hk/mkt/staff/12peng/bus205/Chapter10.ppt

Copyright by author(s); $\underline{\text { CC-BY }}$ 
Kotler, p \& Armstrong, G. 2010. Principles of marketing. Pinelands, Cape Town: Pearson Education South Africa.

Meehan, J., Simonetto, M., Montanm L \& Goodin, C. (2011). Pricing and profitability management: A practical guide for business leaders. Singapore: John Wiley \& Sons. Retrieved from: https://books.google.co.za/books?id=Q5fMZOtlwJMC\&printsec $=$ frontcover\&dq=pricing + management\&hl=en\&sa $=\mathrm{X}$ \&ved=0ahUKEwiR0Lb_vsTLAhWD5BoKHSsYAxsQ6AEINTAB\#v=onepage \&q=pricing\%20management\&f=false Moneyweb. (2007). Tiger Brands admits to bread price-fixing, pays fine. Retrieved from: http://www.moneyweb.co.za/archive/tiger-brands-admits-to-bread-pricefixing-pays-fine/

PFGA. (Not Dated). Pricing \& costing for small businesses. Retrieved from: http://www.pfga.org.au/content/Pricing__Costing_for_Small_Business.pdf

Price Intelligently. (2012). 5 Must know pricing strategy ethics issues. Retrieved from: http://www.priceintelligently.com/blog/bid/164830/5-Must-Know-Pricing-Strategy-Ethics-Issues

Raosoft. (2004). Sample size calculator. Retrieved from: http://www.raosoft.com/samplesize.html

Sibanda, O. S. (2014). The effects of the South African anti-dumping and competition measures upon foreign direct investment. Journal of Buisness and Retail Management Research vol 9(1) p 128 - 134. Retrieved from: $\mathrm{http}: / /$ search.proquest.com/docview/1700401933?pq-origsite=gscholar

Schuler, K. (Not Dated). Pricing strategies for Small Business. [Online] A Retrieved vailable from: http://www.upnorthscore.com/external/documents/advisor/SCORE_Advisor_1013.pdf

Schindler, R. M. (2012). Pricing strategies: A marketing approach. United States: Sage- Retrieved from: factors that impact pricing

Schwarz, E. C., Hunter, J. D \& Lafleur, A. (2013). Advanced theory and practice in Sport Marketing. $2^{\text {nd }}$ ed. New York: Routledge. Retrieved from: https://books.google.co.za/books?id=Np9jyfu1GVQC\&pg=PA182\&dq=price + quality + matrix\&hl=en\&sa=X\&ved=0ah UKEwiDwLjL4Y3MAhVFshQKHZJDBooQ6AEIIjAB\#v=onepage \&q=price $\% 20$ quality $\% 20$ matrix \&f=false

Small Business Development Corporation. (2014). Pricing strategy. Retrieved from: http://www.smallbusiness.wa.gov.au/pricing-strategy/

South Africa info. (2013). South African competition law Retrieved from: http://www.southafrica.info/business/investing/regulations/competition-policy.htm\#.Vw8pIP195hE

Werksmans Attorneys. (Not Dated). Competition \& Antitrust. Retrieved from: http://www.werksmans.com/wpcontent/uploads/2013/04/Competition-Antitrust.pdf

Woolworths holdings. (2012). Trends influencing our strategy. Retrieved from: http://www.woolworthsholdings.co.za/investor/annual_reports/ar2012/integrated/business/industry_trends.asp 


\section{NOTES}

